\title{
PERILAKU KONSUMEN DALAM PROSES PEMBELIAN IKAN HIAS AIR LAUT DI BANDA ACEH AKUARIUM KOTA BANDA ACEH
}

\author{
Nabila Ukhty \\ Fakultas Perikanan, Universitas Teuku Umar
}

Abstract

\begin{abstract}
Competition ornamental fish in Banda Aceh increasingly stringent, requiring appropriate marketing strategies to excel compete. One way that can be taken by employers ornamental fish including Banda Aceh Aquarium, is a strategy to increase sales volume by studying and knowing the factors that influence consumers decide to buy ornamental fish. The purpose of this study was to determine (1) the consumer characteristics of ornamental fish in Banda Aceh Aquarium, (2) ornamental fish type whatever demand by consumers, and (3) factors that influence the purchase of ornamental fish in Banda Aceh Aquarium.The method used in this study is a survey method. The data will be used in this study are primary and secondary data. The sampling technique used was purposive sampling method, with a total sample of 100 respondents. Analysis of the data : (1) descriptive analysis to get an overview of consumer characteristics and type of ornamental fish that consumers demand; (2) factor analysis with factor analysis PCA extraction method. The results showed that the majority of respondents were male (71\%), aged 20-30 years (81\%), unmarried (73\%), family size 3-5 people, educated scholars (49\%), private sector employees (42\%), and the average monthly income of more than $R p$. 2,500,000. Ornamental fish species are widely purchased by consumers in the top five is Clown Fish, Blue Stone, Rivet, Beauty and Six Letter I Dori. The factors that influence consumer decisions in the purchase of ornamental fish are cultural factors, social factors, personal factors, and psychological factors.
\end{abstract}

Keywords: consumer behavior, Banda Aceh aquarium, ornamental fish 


\section{PENDAHULUAN}

Kegiatan perdagangan ikan hias air laut menjadi salah satu primadona di bidang agribisnis perikanan karena selain iklim dan sumberdaya alam Indonesia sangat menunjang, bisnis ini telah terbukti mampu bertahan di saat krisis melanda secara berkepanjangan. Perdagangan ikan hias air laut tak hanya merambah di pasar lokal tetapi juga pasar internasional. Indonesia merupakan salah satu pengekspor penting perdagangan biota laut di dunia baik dari variasi jenis maupun volumenya yang tinggi. Nilai ekspor perikanan hias Indonesia pada tahun 2009 menempati peringkat ketiga sebagai negara eksportir ikan hias dunia setelah Singapura dan Malaysia (Dewan Ikan Hias Indonesia, 2011).

Menurut Muchsin (2007), karakterisitik perdagangan ikan hias laut berbeda dengan karakteristik perdangan ikan hias air tawar. Karakteristik perdagangan ikan hias laut sangat bergantung pada pada kondisi lingkungan dan musim karena secara umum ikan hias air laut merupakan hasil tangkapan dan hingga sekarang pembudidayaan ikan hias air laut belum bisa dilakukan secara maksimal.

Banda Aceh merupakan salah satu daerah yang memiliki potensi dalam perdagangan ikan hias air laut yang ditandai dengan banyaknya masyarakat yang berusaha dengan menjual ikan hias air laut yang berdampak pada persaingan antar pengusaha. Salah satu pengusaha yang bergerak dalam penjualan ikan hias air laut adalah Banda Aceh Aquarium yang berusaha mempertahankan dan meningkatkan jumlah konsumen serta menentukan strategi untuk meningkatkan volume penjualan dengan mempelajari dan mengetahui faktor-faktor apa saja yang mempengaruhi konsumen dalam memutuskan untuk membeli ikan hias air laut.

Tujuan penelitian ini adalah untuk mengetahui: (1) Karakteristik konsumen ikan hias laut di Banda Aceh Akuarium, (2) Jenis ikan hias air laut apa saja yang diminati oleh konsumen, dan (3) Faktor-faktor yang mempengaruhi konsumen dalam membeli ikan hias air laut di Banda Aceh Akuarium.

\section{Kerangka Pemikiran}

Perilaku konsumen merupakan proses yang kompleks dan multi dimensional, karena dalam memahami perilaku konsumen banyak variabel yang mempengaruhi dimana masing- masing variabel dapat saling berinteraksi (Suryani, 2008). Menurut Engel, et al. (1994) dalam Angelina, perilaku konsumen dipengaruhi dan dibentuk oleh faktor pengaruh lingkungan, perbedaan individu, dan proses psikologis. 
Proses keputusan pembelian dimulai saat konsumen mengenali sebuah masalah atau kebutuhan. Pengenalan kebutuhan tergantung pada berapa banyak ketidaksesuaian antara keadaan yang dihadapi konsumen sekarang dan yang akan diinginkan konsumen (Kotler, 2000). Tahap berikutnya adalah dorongan pencarian informasi oleh konsumen akan kebutuhannya. Pemasar perlu memperhatikan sumber-sumber informasi utama yang menjadi acuan konsumen dan pengaruh relatif sumber tersebut terhadap keputusan pembelian selanjutnya.

Pada tahap evaluasi alternatif konsumen melakukan evaluasi pilihan produk dan merek kemudian memilih sesuai dengan yang diinginkan. Tahap berikutnya adalah keputusan pembelian. Sikap orang lain dan situasi yang tidak terantisipasi merupakan faktor yang mempengaruhi konsumen dalam tahap keputusan pembelian.

Tahap terakhir adalah perilaku pasca pembelian. Kepuasan konsumen akan membentuk keyakinan dan sikap yang berpengaruh positif terhadap pembelian berikutnya.

Perilaku pembelian konsumen dipengaruhi oleh faktor budaya, sosial, pribadi dan psikologis (Kotler, 2000).

1. Faktor Budaya : Faktor budaya merupakan penentu keinginan dan perilaku konsumen yang paling mendasar. Faktor tersebut mempunyai pengaruh yang paling luas dan dalam pada perilaku pembelian konsumen (Kotler,2000).

2. Faktor Sosial : Perilaku seseorang banyak dipengaruhi oleh kelompok kecil yang terdiri dari dua orang atau lebih yang saling berinteraksi untuk mencapai sasaran individu atau bersama. Faktor sosial meliputi kelompok acuan, keluarga, serta peran dan status sosial.

3. Faktor Pribadi : Keputusan konsumen juga dipengaruhi oleh karakteristik pribadi. Karakteristik tersebut meliputi usia dan tahap siklus hidup, pekerjaan, keadaan ekonomi, gaya hidup, serta kepribadian dan konsep diri.

4. Faktor Psikologis : Empat faktor psikologis yang mempengaruhi pilihan pembelian seseorang, yaitu motivasi, persepsi, pembelajaran, serta keyakinan dan sikap. 


\section{Kerangka Pemikiran Konseptual}

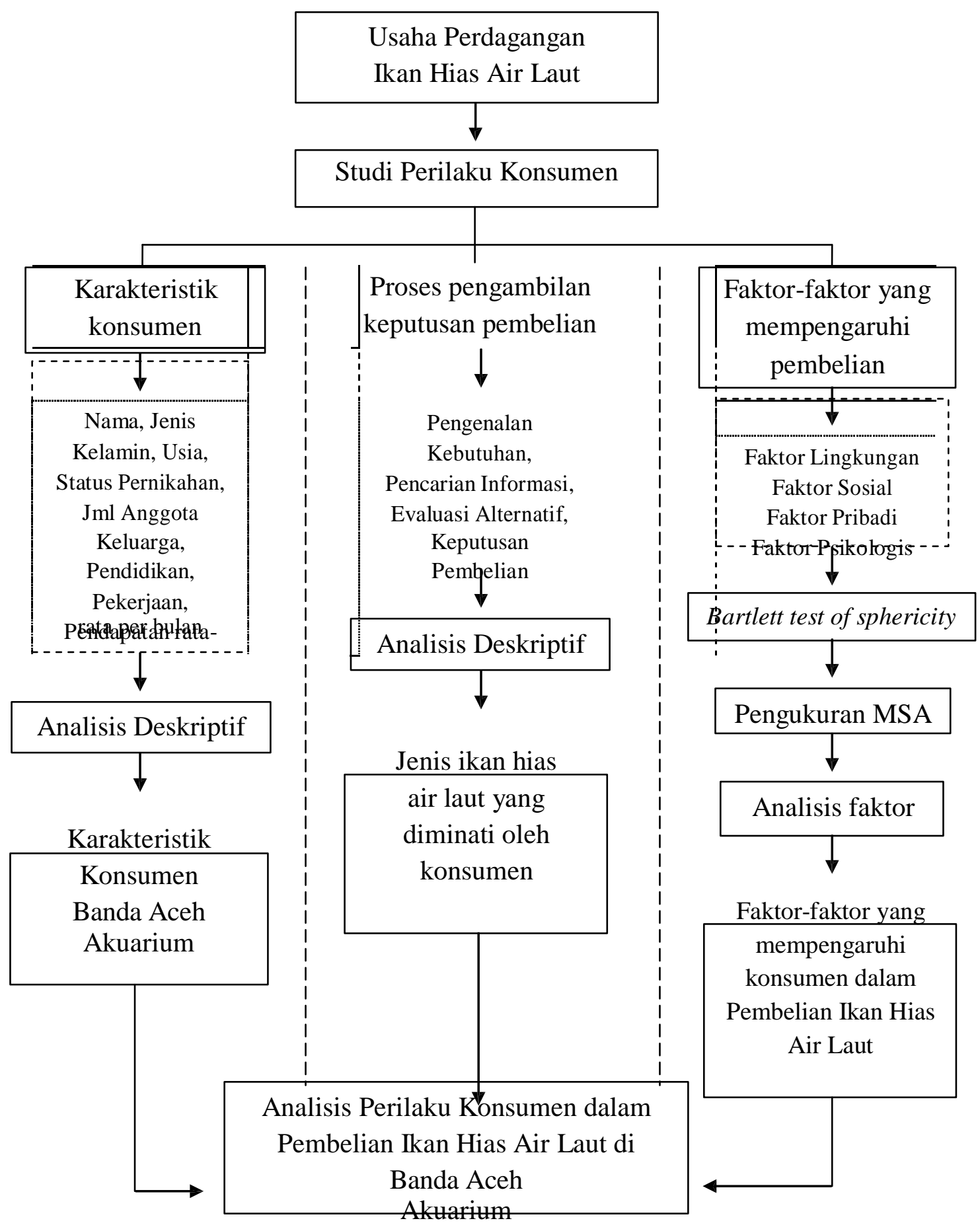

Gambar 1 Kerangka Pemikiran Konseptual 


\section{METODOLOGI PENELITIAN}

Metode yang yang digunakan dalam penelitian ini adalah metode survei. Data yang digunakan dalam penelitian ini adalah data primer dan sekunder. Data primer merupakan data yang didapat dari hasil wawancara sedangkan data sekunder diperoleh dari buku, internet serta literaturliteratur lain yang mendukung penelitian.

Teknik pengambilan sampel yang digunakan dalam penelitian ini adalah metode purpossive sampling karena peluang dari anggota populasi yang dipilih menjadi sampel adalah berdasarkan pertimbangan dan keputusan peneliti. Jumlah sampel yang digunakan dalam penelitian ini adalah sebanyak 100 orang (responden).

Variabel-variabel yang akan diukur dalam penelitian ini terdiri dari 3 bagian, yaitu :

1. Karakteristik Konsumen : (a) nama, (b) jenis kelamin, (c) usia, (d) status pernikahan, (e) jumlah anggota keluarga, (f) pendidikan, (g) pekerjaan, (h) pendapatan rata-rata per bulan.

2. Proses Pengambilan Keputusan : (a) pengenalan kebutuhan : motivasi pembelian, manfaat pembelian; (b) pencarian informasi : sumber informasi, fokus perhatian terhadap informasi yang diperoleh; (c) evaluasi alternatif : factor-faktor pertimbangan dalam melakukan pembelian, lokasi pembelian; (d) kepurusan pembelian : frekuansi, waktu pembelian, jenis ikan hias, cara memutuskan pembelian, besarnya pembelian; (e) evaluasi pembelian : kepuasan, niat membeli ulang.

3. Faktor-faktor yang mempengaruhi proses pembelian : (a) faktor lingkungan : kebiasaan orang tua, kebiasaan lingkungan, agama, tempat tinggal, budaya, dan tingkat pendidikan; (b) faktor sosial : keluarga, penjual, kerabat / saudara, teman, situasi /waktu pembelian, dan status sosial; (c) faktor pribadi : usia, pendapatan, pekerjaan, waktu luang; (d) faktor psikologis : motivasi, pengalaman, jenis ikan hias, kekhasan (warna/bentuk), harga, dan iklan

Analisis Data yang digunakan dalam penelitian ini yaitu : (1) Analisis deskriptif yang digunakan untuk mendapatkan gambaran tentang karakteristik konsumen dan dan jenis ikan hias yang diinginkan oleh responden yang dinyatakan dengan frekuensi, baik angka mutlak atau persentase, (2) Analisis faktor dilakukan dengan metode ekstraksi PCA, untuk menentukan faktorfaktor yang mempengaruhi keputusan konsumen dalam membeli ikan hias air laut

Penelitian ini dilaksanakan di Pasar Ikan Hias Rawalumbu Utara dengan mengambil kasus di Toko Ikan Hias Banda Aceh Akuarium. 


\section{HASIL DAN PEMBAHASAN}

\section{Karakteristik Konsumen Ikan Hias Air Laut di Banda Aceh Akuarium}

Karakteristik umum konsumen ikan hias air laut di toko ikan hias air laut Banda Aceh Akuarium yang diambil sebagai responden dalam penelitian ini didasarkan atas jenis kelamin, usia, status pernikahan, jumlah anggota keluarga, tingkat pendidikan, pekerjaan, dan pendapatan rata-rata perbulan.

Responden terbesar berdasarkan jenis kelamin adalah laki-laki sebanyak 71 orang (71\%), sedangkan responden wanita sebanyak 29 orang (29\%). Hal ini menunjukkan bahwa laki-laki lebih menyukai memelihara ikan hias air laut dibandingkan dengan wanita karena selain memelihara ikan, pemeliharaan akuarium harus dilakukan secara berkala dan mengeluarkan banyak tenaga.

Berdasarkan usianya konsumen Banda Aceh Akuarium mayoritas berusia muda antara 20 - 30 tahun, implikasinya penghobi ikan hias air laut lebih banyak diminati oleh kaum muda yang diduga lebih tertarik dengan kerumitan dan kesulitan dalam filtrasi air laut, dan mereka justru bisa berkreasi dalam penataan filtrasi serta penataan biota-biota lain di akuarium sebagai tempat hidup ikan hias air laut.

Status responden ikan hias Banda Aceh Akuarium sebagian besar adalah belum menikah yaitu sebesar $73 \%$, sedangkan yang sudah menikah hanya sebesar 27\%. Alasannya diduga bahwa orang yang belum menikah lebih tertarik dalam memelihara ikan hias air laut dalam akuarium.

Sebagian besar konsumen ikan hias air laut di Banda Aceh Akuarium memiliki jumlah anggota keluarga tidak lebih dari 5 orang. Hal itu menunjukkan bahwa dengan jumlah anak maksimum tiga orang masih mempunyai waktu luang untk memelihara ikan hias dalam akuarium secara intensif.

Tingkat pendidikan sangat mempengaruhi seseorang dalam membeli ikan hias air laut. Selain sebagai hobi dalam memelihara ikan hias, kesadaran dan pengetahuan konsumen dalam memperindah ruangan dan menata agar tempat tinggalnya menjadi lebih indah juga terbangun. Hal tersebut tercermin dari sebagian besar konsumen ikan hias air laut berpendidikan sarjana.

Karakteristik responden berdasarkan pekerjaan menunjukkan bahwa sebagian besar responden berprofesi sebagai pegawai swasta yaitu sebesar 42\%, mahasiswa/pelajar 33\%, wiraswasta 22\% dan 3\% sebagai Pegawai Negeri Sipil (PNS). Kondisi in diduga antara lain tingkat 
stress pegawai swasta lebih tinggi dibandingkan PNS sehingga diperlukan suasana yang mampu menenangkan salah satunya memelihara ikan hias air laut.

Berdasarkan tingkat pendapatan responden, sebagian besar berpenghasilan di atas Rp. 2.5 juta per bulan yaitu sebesar 56\%. Artinya tingginya pendapatan akan berpengaruh terhadap daya beli seseorang untuk membeli ikan hias air laut.

\section{Proses Pengambilan Keputusan Pembelian Ikan Hias Air Laut}

Alasan dan motivasi responden dalam membeli ikan hias air laut di Toko Banda Aceh Akuarium adalah karena hobi yakni sebesar $62 \%$ dan hanya $1 \%$ yang terpengaruh faktor harga. Hal ini menunjukkan bahwa harga suatu ikan hias air laut bukan alasan utama seseorang untuk membeli ikan hias air laut. Berapapun harga suatu ikan hias air laut akan tetap dibayar selama konsumen menyukainya.

Berdasarkan hasil penelitian, manfaat yang diharapkan responden dengan memelihara ikan hias adalah sebagai penghias rumah $(65 \%)$ dan hanya $29 \%$ yang mengharap sebagai gaya hidup. Namun ada sebagian responden mengharap manfaat membeli ikan hias air laut ini sebagai investasi.

Tahap kedua dalam proses keputusan pembelian adalah pencarian informasi. Beberapa sumber informasi yang digunakan oleh responden untuk mendapatkan informasi tentang ikan hias air laut adalah berasal dari teman yaitu sebesar 43\%, 29\% berasal dari koran/media/tabloid/TV, dan $16 \%$ dari penjual. Peran seorang teman sangat besar dalam memberikan pengaruh sehingga konsumen tertarik untuk membeli ikan hias air laut.

Hasil penelitian menunjukkan bahwa mayoritas konsumen lebih memilih jenis ikan hias air laut (68\%). Hal ini memperlihatkan bahwa konsumen dalam membeli ikan hias air laut yang mereka inginkan tidak mempertimbangkan harga ataupun pelayanan. Kemudahan meperoleh ikan hias juga mempengaruhi konsumen yaitu sebesar 29\%. Hal tersebut menunjukkan bahwa konsumen ikan hias air laut akan berusaha mendapatkan ikan hias yang diinginkan meskipun untuk mendapatkan ikan hias air laut tergolong sulit baik karena jumlah barang yang terbatas maupun harganya yang relatif mahal.

Tahap ketiga dalam proses keputusan pembelian adalah evaluasi alternatif. Konsumen melakukan pembelian ikan hias melalui tahapan evaluasi alternatif yang manentukan seseorang untuk mempertimbangkan untung ruginya dalam membeli barang tertentu yang sesuai dengan apa yang mereka inginkan. Adapun beberapa hal yang menjadi pertimbangan 
konsumen dalam pembelian ikan hias air laut di Banda Aceh Akuarium dapat dilihat pada Tabel 1.

Tabel 1 Faktor yang Menjadi Pertimbangan Konsumen dalam Pembelian Ikan Hias Air Laut di Banda Aceh Akuarium

\begin{tabular}{llcc}
\hline No & Faktor Pertimbangan & Jumlah (orang) & Persentase (\%) \\
\hline 1 & Harga & 13 & 13 \\
2 & Jenis Ikan Hias Air Laut & 38 & 38 \\
3 & Bentuk Ikan Hias Air Laut & 14 & 14 \\
4 & Warna Ikan Hias Air Laut & 35 & 35 \\
5 & Lainnya & 0 & 0 \\
\hline & Jumlah & 100 & 100 \\
\hline
\end{tabular}

Tabel 1 menunjukkan bahwa jenis, warna dan bentuk ikan hias air laut merupakan faktor utama seseorang untuk membeli ikan hias air laut. Faktor harga bukan alasan utama seseorang dalam melakukan pembelian ikan hias aair laut. Hal tersebut terlihat hanya $13 \%$ responden saja yang memilih karena alasan harga.

Perilaku konsumen ikan hias air laut di Banda Aceh Akuarium ketika mendapati ikan hias yang mereka inginkan tidak ada mereka cenderung akan mencari ke tempat lain yakni $46 \%$, tidak jadi membeli $26 \%$ dan membeli jenis yang lain sebesar $25 \%$.

Mayoritas pembelian ikan hias air laut di Toko ikan Hias Banda Aceh Akuarium dilakukan pada hari libur yaitu sebesar $74 \%$. Pembelian yang dilakukan pada hari kerja hanya sebesar $26 \%$. Pembelian pada hari libur banyak dilakukan dibandingkan pada hari kerja karena pada hari libur konsumen memiliki lebih banyak waktu luang.

Jenis ikan hias air laut yang paling banyak diminati oleh konsumen di Banda Aceh Akuarium adalah Clown Fishyakni (41\%). Clown fish (nemo) dipilih karena selain warna ikannya yang menawan, ikan ini mempunyai tingkat adaptasi yang cukup bagus dan tidak memerlukan perawatan yang spesial sehingga mudah untuk dipelihara di dalam akuarium air laut. 

dana sebesar Rp. 25.000 - Rp. 102.000. Hal tersebut menandakan bahwa konsumen ikan hias air laut juga realistis terhadap harga ikan hias air laut.

\section{Faktor-faktor yang Mempengaruhi Proses Pembelian Ikan Hias Air Laut}

Tabel Anti Image Matrices pada penelitian ini menunjukkan bahwa semua variabel memiliki nilai MSA (Measure of Sampling Adequacy) lebih dari 0,5 sehingga semua variabel dapat dianalisis lebih lanjut dengan nilai communality.

Pelayanan merupakan variabel dengan communality terbesar $(0,828)$. Hal ini menunjukkan bahwa pelayanan hubungannya sangat erat dengan keputusan pembelian ikan hias air laut. Pelayanan merupakan bagian dari sikap yang ditunjukkan oleh penjual kepada konsumen yang akan mempengaruhi psikologis konsumen.

Tabel Componen Matrix menunjukkan terdapat 22 variabel yang didistribusi pada faktorfaktor yang terbentuk. Variabel-variabel tersebut menghasilkan nilai loading yang menunjukkan besarnya korelasi variabel dengan faktor yang terbentuk. Hasil Componen Matrix menunjukkan bahwa 22 variabel berkorelasi sangat kuat terhadap faktor 1 yang terbentuk yaitu kebiasaan lingkungan. Faktor-faktor yang mempengaruhi dan nilai loading komponen utama dapat dilihat pada Tabel 2.

Tabel 2 Faktor-faktor yang Mempengaruhi dan Nilai Loading

\begin{tabular}{lll}
\hline Komponen Utama & Variabel & Nilai Loading \\
\hline Budaya & Kebiasaan Lingkungan & 0.737 \\
Budaya & Budaya & 0.721 \\
Psikologis & Motivasi & 0.687 \\
Budaya & Pendidikan & 0.686 \\
Sosial & Keluarga & 0.669 \\
Budaya & Kebiasaan Orang Tua & 0.663 \\
Sosial & Kerabat/Saudara & 0.654 \\
Sosial & Penjual & 0.651 \\
Sosial & Status Sosial & 0.650 \\
Budaya & Tempat Tinggal & 0.640 \\
Psikologis & Pelayanan & 0.630 \\
Pribadi & Pekerjaan & 0.618 \\
Sosial & Teman & 0.609
\end{tabular}


Pribadi

Usia

0.589

Psikologis

Kekhasan

0.564 


\begin{tabular}{lll}
\hline Komponen Utama & Variabel & Nilai Loading \\
\hline Psikologis & Jenis & 0.562 \\
Pribadi & Pendapatan & 0.519 \\
Budaya & Agama/Kepercayaan & 0.505 \\
Sosial & Situasi & 0.413 \\
Psikologis & Harga Ikan Hias & 0.319 \\
Pribadi & Waktu Luang & 0.314 \\
Psikologis & Iklan dan Promosi & 0.205 \\
\hline
\end{tabular}

\section{Komponen Utama Sosial}

Komponen utama sosial terdiri dari variabel keluarga, penjual, saudara/kerabat, teman, situasi/waku pembelian, dan status sosial dengan nilai loading terbesar 0,669 pada variabel keluarga. Meskipun demikian, variabel kerabat/saudara dan penjual mempunyai nilai loading dengan selisih yang tidak terlalu jauh yaitu sebesar 0,654 dan 0,651. Keluarga dapat mempengaruhi keputusan pembelian seseorang. Keluarga mempunyai pengaruh langsung maupun tidak langsung terhadap keputusan pembelian.

Pilihan konsumen terhadap suatu produk dipengaruhi oleh lingkungan yang mengitarinya. Ketika konsumen membeli suatu produk didasari oleh banyak pertimbangan, misalnya karena meniru temannya, karena tetangganya telah membeli lebih dulu dan sebagainya. Dengan demikian, interaksi sosial yang dilakukan seseorang akan turut mempengaruhi pilihan produk yang dipilih.

Pembelian suatu produk juga dipengaruhi oleh penjual yang merupakan penerapan dari strategi pemasaran. Dalam hal ini penjual berusaha mempengaruhi konsumen dengan menggunakan berbagai stimulus seperti iklan dan sejenisnya agar konsumen tertarik dan bersedia memilih dan membeli produk yang ditawarkan.

\section{Komponen Utama Pribadi}

Komponen ini disusun oleh beberapa variabel yaitu usia, pendapatan, pekerjaan, dan waktu luang. Nilai loading terbesar dalam pembentukan komponen pribadi adalah variabel pekerjaan dengan nilai 0,618 .

Pekerjaan seseorang mempengaruhi pembelian barang dan jasa. Hal tersebut berkaitan dengan pendapatan yang diterimanya. Pemasar produk yang peka terhadap pendapatan akan mengamati kecenderungan dalam pendapatan pribadi, tabungan, dan tingkat minat. Bila indikator ekonomi menunjukkan resesi, pemasar dapat mengambil langkah- langkah untuk merancang ulang, memposisikan kembali, dan mengubah harga produknya. 


\section{Komponen Utama Psikologis}

Komponen utama psikologis disusun oleh enam variabel yaitu motivasi, pelayanan, jenis ikan hias air laut, harga dan iklan. Nilai loading terbesar pada variabel ini adalah motivasi yakni sebesar 0,687. Motivasi berkorelasi sangat kuat terhadap faktor 1 yang terbentuk. Hal tersebut menunjukkan bahwa motivasi seseorang berpengaruh terhadap keputusan pembelian. Motivasi mewakili dorongan untuk memuaskan kebutuhan psikologis melalui pembelian dan penggunaan suatu produk.

\section{Komponen Utama Budaya}

Komponen budaya merupakan penyebab paling mendasar dari keinginan dan perilaku seseorang karena budaya tumbuh dalam suatu masyarakat dari sejak kecil. Komponen budaya terdiri dari variabel kebiasaan orang tua, kebiasaan lingkungan tempat tinggal, agama/kepercayaan, tempat tinggal, pendidikan dan budaya. Nilai loading terbesar pada komponen ini adalah variabel kebiasaan lingkungan tempat tinggal dengan nilai sebesar 0,737 . Hal tersebut menunjukkan bahwa kebiasaan lingkungan tempat tinggal konsumen dalam menata ruangan tempat tinggalnya agar senantiasa menarik dan indah dengan menghadirkan akuarium ikan hias air laut.

\section{SIMPULAN}

Mayoritas responden adalah laki-laki (71\%), berusia 20-30 tahun (81\%), belum menikah (37\%) anggota keluarga 3-5 orang (73\%), berpendidikan sarjana (49\%) karyawan swasta (42\%), dan pendapatan rata-rata perbulan lebih dari Rp. 2.500.000. Jenis ikan hias air laut yang banyak dibeli oleh konsumen dalam lima besar adalah Badut/Clown Fish, Blue Stone, Keling, Cantik dan Letter Six/Dori. Faktor-faktor yang mempengaruhi keputusan konsumen dalam pembelian ikan hias adalah faktor budaya, faktor sosial, faktor pribadi, dan faktor psikologis. Variabel-variabel yang mempengaruhi proses pembelian adalah kebiasaan orang tua, kebiasaan lingkungan, agama, tempat tinggal, budaya, tingkat pendidikan, keluarga, penjual, kerabat/saudara, teman, situasi/waktu pembelian, status sosial, usia, pendapatan, pekerjaan, waktu luang, motivasi, pelayanan, jenis ikan hias air laut, kekhasan, harga, dan iklan. Sebaiknya dilakukan penelitian lanjutan untuk melihat keberhasilan strategi pemasaran ikan hias air laut dan apakah faktor manajerial dapat mempengaruhi keputusan pembelian. 


\section{DAFTAR PUSTAKA}

Anggraeni, Putu Widyastuti. 2004. "Pengusahaan Ikan Hias Laut secara Berkelanjutan" Tesis Ilmu Lingkungan, Universitas Indonesia.

Dewan Ikan Hias Indonesia, 2011, "Dewan Ikan Hias Indonesia" http://www.perikananbudidaya.kkp.go.id /index.php?option=com_content\&view=article\&id=333:dewanikan-hias-indonesia\&catid=148:sekretariat\&Itemid=144. Didownload pada bulan November 2012. Diakses pada Bulan Desember 2012

Kotler, P. 2000. Marketing Management, Prentice-Hall, Inc. Upper Saddle River, New Jersey

Muchsin, Musliyadi. 2007. Analisis Kepuasan Pengunjung Toko Ikan Hias Air Laut Tropical Akuarium di Kotamadya Bogor. Skripsi Manajemen Agribisnis, Institut Pertanian Bogor.

Nugroho J. Setiadi, 2005. Perilaku Konsumen, Konsep, dan Implikasi untuk Strategi dan Penelitian Pemasaran, Penerbit Prenada Media, Jakarta.

Santoso, Singgih. 2012. Aplikasi SPSS pada Statistik Multivariat. PT Elex Media Komputindo Gramedia. Jakarta.

Sembiring, BR Angelina. 2006. Analisis Perilaku Konsumen dalam Proses Keputusan Pembelian Makanan di Restoran Bakmi Japos Bogor. Skripsi Ekonomi dan Manajemen, Institut Pertanian Bogor.

Simamora, Bilson. 2004. Riset Pemasaran-Falsafah, Teori dan Aplikasi, Penerbit PT Gramedia Pustaka Utama Jakarta.

Suryani, Tatik. 2008. Perilaku Konsumen-Implikasi pada Strategi Pemasaran, Penerbit Graha Ilmu, Yogyakarta 